\section{Safe disposal of unwanted pharmaceuticals in and after emergencies ${ }^{1}$}

1 Based on: World Health Organization, Department of Essential Drugs and Other Medicines. Guidelines for safe disposal of unwanted pharmaceuticals in and after emergencies. Geneva: WHO; 1999. Available from: http://www.who.int/medicines/docs/ edmguidelines.html. Accessed 24 January 2000.
During conflicts and natural disasters large quantities of pharmaceuticals are often donated as part of humanitarian assistance efforts. Drug donations are also frequently one component of ongoing international development assistance programs. Many of these donated pharmaceuticals save lives and alleviate suffering, but some contributions by wellmeaning but uninformed people may cause problems. For example, the pharmaceuticals may arrive past or near their expiry date, or they may be inappropriate for the needs. Sometimes the pharmaceuticals are unrecognizable because they are labeled in a foreign language, or they may have been sent in unwanted quantities $(1,2)$.

Safe disposal of these unwanted or expired drugs often creates a major problem and can entail heavy expense. In Bosnia and Herzegovina, for instance, between 1992 and mid-1996 an estimated 17000 metric tons of inappropriate donations were received, with a disposal cost of some US\$ 34 million. In Eritrea during the war for independence inappropriate donations caused many difficulties. It took workers six months to burn seven truckloads of expired aspirin tablets, and 30000 half-liter bottles of expired amino-acid infusion could not be disposed of near inhabited areas because of the smell (1).

Improper disposal or nondisposal of unwanted drugs can create a variety of difficulties. Inappropriate disposal may contaminate water supply systems or local water sources used by nearby residents or wildlife. Expired drugs dumped into an insecure landfill may fall into the hands of scavengers or children. Waste drugs may be pilfered from a stockpile and then diverted to the market for resale and misuse. Nonbiodegradable antibiotics, antineoplastics, and disinfectants emptied into the sewage system may kill bacteria necessary for sewage treatment. Burning pharmaceuticals at low temperatures or in open containers can release toxic pollutants into the air.

To help countries better handle these kinds of situations, the Department of Essential Drugs and Other Medicines of the World Health Organization (WHO) recently issued a new publication, Guidelines for safe disposal of unwanted pharmaceuticals in and after emergencies. Rather than superseding local, regional, or national laws on drug disposal, the new WHO guidelines are intended to provide assistance in situations where there is insufficient guidance or none at all. 


\section{Disposal steps}

In disposing of unwanted pharmaceuticals, the first step needed is for a hospital, district or regional pharmacist, or organizations with pharmaceutical programs to make a clear decision that there has been an accumulation of unwanted pharmaceuticals that are unfit for human consumption and for veterinary treatment.

Approval and sanctioning of disposal of pharmaceuticals should come from the appropriate authority. This authority will differ from country to country. It might be the department responsible for pharmaceutical management within the ministry of health, the drug regulatory authority, or the regional or local health authority (pharmaceutical officer).

Also needed is planning, in terms of funding, necessary expertise, human resources, professional time, space, equipment, material, and available disposal options. This is essential before practical steps can be taken to start disposal.

A pharmacist should supervise each work team, which should preferably consist of pharmaceutical technicians or experienced pharmaceutical warehouse personnel. The size of each team, and the ratio of experts to workers, will depend on the volume and composition of the stockpiles and the working conditions at the sites.

For their health and safety, at all times workers should wear appropriate protective equipment, including overalls and boots, as well as gloves, masks, and caps when needed, such as when tablets or capsules are being crushed as part of the disposal process.

Sorting is done to separate pharmaceuticals according to the appropriate disposal method. Among the pharmaceuticals that will require special disposal methods are antibiotics, antineoplastic drugs, and such controlled substances as narcotics and psychotropics. Sorting may entail a substantial investment in human resources.

\section{Disposal methods}

The ideal approach to disposing of unwanted pharmaceuticals is through incineration at a temperature above $1200{ }^{\circ} \mathrm{C}$, in specially built incinerators with adequate flue-gas cleaning. Such incineration facilities are mainly found in the industrialized world, but this is not the only method that can be used to achieve adequate disposal. There are a number of treatments and disposal techniques that are only slightly less safe and that are acceptable when balanced against the risks of improper disposal or nondisposal. These alternative methods involve minimal risks to public health and the environment, and include ones suitable for countries with limited resources and equipment.

One possibility for disposing of unwanted pharmaceuticals is to return them to the donor or manufacturer. This may be especially appropriate with drugs that present disposal problems, such as antineoplastics, and for unwanted, unrequested donations that arrive past or unreasonably near their expiry date.

Landfilling is another option. There are three types of landfilling, or placing waste directly into a land disposal site without prior treatment or preparation: an open uncontrolled nonengineered dump, an engineered landfill, and a highly engineered sanitary landfill.

While an open uncontrolled nonengineered dump is probably the most common land disposal method in developing countries, this should be avoided except as a last resort. Where it is not possible to immobilize the waste pharmaceuticals by encapsulation or inertization, then the untreated wastes must be covered rapidly with large quantities of municipal waste to prevent scavenging.

An engineered landfill has some features to protect from loss of chemicals into the aquifer. Discharging immobilized pharmaceutical waste into such a landfill is preferable to the direct deposit of pharmaceuticals.

A highly engineered sanitary landfill offers a relatively safe disposal route for municipal solid wastes, including waste pharmaceuticals. The top priority is protection of the aquifer. An appropriate landfill consists of an evacuated pit isolated from watercourses and above the water table. Each day's solid waste is compacted and covered with soil to maintain sanitary conditions.

Encapsulation is one of two possible forms of immobilizing unwanted pharmaceuticals in a solid block within a plastic or steel drum. Drums are cleaned and then filled to $75 \%$ capacity with solid and semisolid pharmaceuticals. The remaining space in the drum is filled by pouring in a medium such as cement or a cement-lime mixture, plastic foam, or bituminous sand. After being sealed, the drums are placed at the base of a landfill and covered with fresh municipal solid waste.

Inertization is a variant of encapsulation. It involves removing the packaging materials, paper, cardboard, and plastic from the pharmaceuticals. The pharmaceuticals are then ground and a mix of water, cement, and lime added to form a homogenous paste. The paste is then transported in the liquid state by concrete mixer truck to a landfill and decanted into the normal urban waste. The paste then sets as a solid mass dispersed within the municipal solid waste. 
TABLE 1. Pharmaceutical categories and disposal methods in and after emergencies

\begin{tabular}{|c|c|c|}
\hline Category & Disposal methods & Comments \\
\hline $\begin{array}{l}\text { Solids } \\
\text { Semisolids } \\
\text { Powders }\end{array}$ & $\begin{array}{l}\text { Landfill } \\
\text { Waste encapsulation } \\
\text { Waste inertization } \\
\text { Medium- and high-temperature incineration (cement kiln } \\
\quad \text { incinerator) }\end{array}$ & $\begin{array}{l}\text { No more than } 1 \% \text { of the daily municipal waste } \\
\text { should be disposed of in an untreated form } \\
\text { (nonimmobilized) to a landfill. }\end{array}$ \\
\hline Liquids & $\begin{array}{l}\text { Sewer } \\
\text { High-temperature incineration (cement kiln incinerator) }\end{array}$ & Antineoplastics not to sewer. \\
\hline Ampules & Crush ampules and flush diluted fluid to sewer & Antineoplastics not to sewer. \\
\hline Antiinfective drugs & $\begin{array}{l}\text { Waste encapsulation } \\
\text { Waste inertization } \\
\text { Medium- and high-temperature incineration (cement kiln } \\
\text { incinerator) }\end{array}$ & $\begin{array}{l}\text { Liquid antibiotics may be diluted with water, } \\
\text { left to stand for several weeks, and then } \\
\text { discharged to a sewer. }\end{array}$ \\
\hline Antineoplastics & $\begin{array}{l}\text { Return to donor or manufacturer } \\
\text { Waste encapsulation } \\
\text { Waste inertization } \\
\text { High-temperature incineration } \\
\text { Chemical decomposition }\end{array}$ & Not to landfill unless encapsulated. \\
\hline Controlled drugs & $\begin{array}{l}\text { Waste encapsulation } \\
\text { Waste inertization } \\
\text { Medium- and high-temperature incineration (cement kiln } \\
\text { incinerator) }\end{array}$ & Not to landfill unless encapsulated. \\
\hline Aerosol canisters & $\begin{array}{l}\text { Landfill } \\
\text { Waste encapsulation }\end{array}$ & Not to be burned; may explode. \\
\hline Disinfectants & $\begin{array}{l}\text { Store and use over time } \\
\text { To sewer or fast-flowing watercourse: small quantities of } \\
\text { diluted disinfectants (maximum of } 50 \text { liters per day } \\
\text { under supervision) }\end{array}$ & $\begin{array}{l}\text { No undiluted disinfectants to sewers or } \\
\text { watercourses. } \\
\text { No disinfectants at all to slow-moving or } \\
\text { stagnant watercourses. }\end{array}$ \\
\hline PVC plastic, glass & Landfill & Not for burning in open containers. \\
\hline Paper, cardboard & Recycle, burn, landfill & \\
\hline
\end{tabular}

Some liquid pharmaceuticals, such as syrups and intravenous fluids, can be diluted with water and flushed into the sewers in small quantities over a period of time. Fast-flowing watercourses may likewise be used to flush small quantities of welldiluted liquid pharmaceuticals or antiseptics.

In emergency situations in countries where no high-temperature incinerators are available, municipal medium-temperature incinerators are a possible interim approach that is preferable to less safe options, such as inadequate discharge to a landfill. In such cases, the pharmaceutical waste should be diluted with large quantities of municipal waste (approximately 1:1 000).

A novel incineration approach available in many countries is the use of industrial plants that use high-temperature technology, such as cement kilns, coal-fired thermal power stations, or foundries, and that disperse exhaust gases via tall chimneys. Cement kilns are particularly suited for the disposal of expired pharmaceuticals. Pharmaceuticals should be introduced into the kiln furnace as a reasonably small proportion of the total fuel feed, generally no more than $5 \%$ of the fuel fed into the furnace at any one time. Cement kilns typically produce 1500 to 8000 metric tons of cement per day and can therefore handle large quantities of pharmaceutical material in a short period of time.

The most appropriate disposal method will depend on the category of pharmaceuticals; Table 1 provides general guidance for various classifications of pharmaceuticals.

\section{Public information}

Good public relations, including comprehensive dissemination of information, is an important ele- 
ment in achieving satisfactory safe disposal of unwanted pharmaceuticals. Among the key points to present to the media are:

- The vast majority of pharmaceuticals are donated with the intention to help, and there are only rare occurrences of "dumping" by unscrupulous companies to gain tax relief or to get rid of unwanted stock.

- When pharmaceuticals pass their expiry date they do not automatically become hazardous, they simply becomes less efficacious.

- The risk from disposal of pharmaceuticals is low provided the task is properly handled.

- Disposal of pharmaceuticals should be carried out under the supervision of regional and national authorities, who organize it according to strict criteria; disposal should not be done by individuals.

Information on pharmaceutical disposal must be carefully handled so it does not become politicized and sensationalized. If the media and politicians are not kept judiciously informed, erroneous reports they spread may severely hamper the disposal work.

\section{SINOPSIS}

\section{La disposición segura de productos farmacéuticos inservibles durante emergencias y después}

Los medicamentos donados pueden mitigar el sufrimiento humano después de un desastre natural o cuando forman parte de un programa continuo de fomento y desarrollo internacional. No obstante, algunas contribuciones de este tipo son problemáticas, bien sea porque los medicamentos llegan ya caducados, no son los que se necesitan o están rotulados en un idioma extranjero que nadie conoce. La disposición segura de estos medicamentos inservibles o vencidos a menudo ocasiona grandes dificultades y puede entrañar enormes costos. Nuevas pautas emitidas por la Organización Mundial de la Salud proveen orientación sobre qué hacer en situaciones como estas. Las pautas enumeran los pasos para disponer de los productos farmacéuticos inservibles, las distintas opciones de desecho y la manera de separar los productos en distintas categorías, según la forma de eliminación que cada una exija.

\section{REFERENCES}

1. World Health Organization, Department of Essential Drugs and Other Medicines. Guidelines for drug donations. 2nd edition. Geneva: WHO; 1999.
2. Guidelines for drug donations. Rev Panam Salud Publica 2000;7(2):131-134. 